\title{
The Impact of Perceived e-WOM on Purchase Intention: The Mediating Role of Corporate Image
}

\author{
Abdallah Q. Bataineh ${ }^{1}$ \\ ${ }^{1}$ Department of Marketing, Faculty of Economics and Administrative Sciences, Applied Science University, \\ Jordan \\ Correspondence: Abdallah Q. Bataineh, Department of Marketing, Faculty of Economics and Administrative \\ Sciences, Applied Science University, Amman, Jordan. E-mail: a_bataineh@asu.edu.jo
}

Received: December 22, 2014 Accepted: January 10, 2015 Online Published: January 26, 2015

doi:10.5539/ijms.v7n1p126 URL: http://dx.doi.org/10.5539/ijms.v7n1p126

\begin{abstract}
The main objective of this research is to examine the impact of perceived electronic word of mouth (eWOM) on purchase intention; by taking the corporate image as mediating variable. This research adopted the customers' views; secondary schools students who are familiar and have an active account on one or more of these social networking sites (Facebook, Twitter, Youtube, and Instagram). The conceptual framework of this study was tested using data gathered from the questionnaires directed to a total sample of 1000 students located in Amman. The statistical results of the multiple regression test indicated that eWOM quality, eWOM credibility, and eWOM quantity respectively; are significantly and positively impact purchase intention. In terms of the mediating role of corporate image the results indicated that corporate image mediate the relationship between the independent and dependent variables. Accordingly, Research conclusion, recommendations and future research are also discussed.
\end{abstract}

Keywords: perceived eWOM (eWOM credibility, eWOM quality, eWOM quantity), corporate image, purchase intention, education sector, Jordan

\section{Introduction}

The fast growth of the Internet with its improved communication capabilities has considerably amplified the scale and scope of word-of-mouth WOM communication; which presented a fertile base for electronic word-of-mouth (eWOM) communication. For the most part, the Internet's far-reaching, transparency, and accessibility have set new meaning to WOM concept, and that's what made marketers more interested to get involve in WOM activities (Kozinets et al., 2010). Regardless of the buzz neighboring counterfeit online business ratings and reviews, customers haven't stopped reading other people's posts about their experiences with firms. The escalating use of companies' social networking sites (SNSs) presents customers with high opportunities to start searching for more trusted information about products, and simultaneously; permit customers to provide their own experience with the products. According to emarketer (2014) report; respondents still read more online reviews before putting trust in a local business. As well as, in order to exchange product information; customers started increasingly use various types of Web 2.0 tools e.g., customer review sites, weblogs, social network sites, online discussion forums etc., (Lee, Park, \& Han, 2008). The influence of conventional marketing efforts seems to be on the way out (e.g., Sweeney et al., 2008; Gil-Or, 2010). Moreover, custmers are now clearly can be described as vehicles to spread communication (San José-Cabezudo \& Camarero-Izquierdo, 2012). The concept of eWOM emerged in marketing literatures only one decade ago (Breazeale, 2009). Because of that; the concept is not considered as a precise concept among schoolers and practitioners. Therefore, eWOM reflects a precious area of research to be examined. According to the literatures, the influence of eWOM communication has been classified into two levels: (1) Market-level analysis and (2) Individual-level analysis (Lee \& Lee, 2009). At the market-level analysis, researchers were paying high attention to the market parameters e.g., sales volume; whereas in the second level; the researchers assumed eWOM as a personal influence process, in which communications among a communicator (sender) and a receiver can change the receiver's attitude toward buying decision (Park \& Lee, 2008, Cheung, Lee, \& Thadani, 2009). As a consequence, this research will try to highlits on the individual-level of eWOM. According to the (2013) Survey provided by Pew Global Attitudes; the survey demonstrated that Lebanon take the lead in Internet usage rate 
with (57\%) in the Arab world, while Jordan ranked second with (47\%), and respectively; Egypt (43\%), Tunisia (40\%). In addition, $84 \%$ of Jordanian internet users are using SNSs, keeping in touch with family and friends is highest driver for them to use SNSs. The survey also indicated that $(63 \%)$ of total SNSs users in Jordan share opinions about politics, while (69\%) share their views about music, and finally (64\%) share views about religion.

Its known that the university represents high involvement service experience; students become overtime more familiar with the university's (facilities, services, majors, courses, teachers, and even non-academic activities such as social works, entertainment, trips, etc.) thus, the university student's recommendations of the whole experience at the university reflects an appropriate and fertile area to explore the role of eWOM in formulating a clearer picture between prospect student's for their future favorable university. Moreover, as a result of the increased availability of online recommendations and evaluation information; secondary schools students might depend seriously on opinions provided by those graduates or undergraduates while making their choices of a certain university. In view of that, the purpose of this research is to examine the impact of eWOM factors including (eWOM credibility, eWOM quality, and eWOM quantity) on purchase intention between secondary schools students in Jordan.

\section{Conceptual Framework and Hypothesis Development}

\subsection{Perceived eWOM}

In the field of social psychology, a great attention was given to the interpersonal communication; studies in this line have without fail explained how personal influence impacts persons to make choices. The traditional phrase word of mouth (WOM) can be defined as "a process of sharing opinions and information about specific product between customers" (Jalilvand et al., 2011). Regarding the context of the internet and online channels; the eWOM describes any negative or positive statement made by current or prospects customers about the organization or its products by the use of the Internet (Hennig-Thurau et al., 2004). Likewise, the concept eWOM might occur in different settings; customers can post their comments, opinions and reviews of products and services on different channels; like discussion forums, weblogs, review websites, and social networking sites (e.g., facebook, Youtube, Twitter etc.). According to Hennig-Thurau et al. (2004) marketing professionals needs to pay more attention for eWOM communications. For many researchers, the eWOM concept seems to be the cornerstone of the promotional mix (e.g., Shu-Chuan \& Yoojung, 2011, Yeh \& Choi, 2011). A lot of customers preferred reading suggestions given by experienced customers before buying certain types of products or services, especially those related to product information in general, opinions given by experienced customers were found to significantly have an effect on new customers' purchasing decision-making (Senecal \& Nantel, 2004). While many customers search for comments about products and service online during pre purchasing stage, a lot of customers also shared opinions both positive and negative comments about their experience of using the products and services online at the post purchasing stages (Frambach, Roest, \& Krishnan, 2007). Throughout direct and continous interacting with customers; marketers can drive customers to carry out more effective eWOM behaviors from different platforms. The variety of online platforms includes: corporate official websites, online communities, newsgroups, chat rooms, emails, blogs, microblogs, customer review websites, virtual customer communities, forums and other SNSs; enabled customers to interact with each others swiftly and easily without boundaries (Strutton et al., 2011, San José-Cabezudo \& Camarero-Izquierdo, 2012). The marketers' ability to recognize the key reasons behind customer's engagement in eWOM communications; can establish clearer picture in which eWOM affects buying decisions (Goldsmith and Horowitz, 2006). In this research, perceived eWOM is defined as the extent to how secondary schools students can perceive marketing related information (e.g., reviews/comments), provided by graduates or undergraduates universities students through social networking sites, like (Facebook, Twitter, Youtube, and Instagram). As well as, the concept of eWOM in this research will be viewed through three dimensions (eWOM credibility, eWOM quality, and eWOM quantity).

\subsection{1 eWOM Credibility}

Customers perceive interpersonal communication about product and services as more dependable source of information than marketer-generated content (Mangold \& Faulds, 2009). The receiver's judgment of the information credibility consider as a key of early stage of information persuasion process (Hilligoss \& Rieh, 2008). The eWOM credibility refers to the extent to which one perceives the recommendation from certain source whether person/organizations as believable (Fogg et al., 2002). If the customers perceived the products and services reviews/comments as credible source, they might use it to make their purchasing decision. In contrast, if it is perceived as less credible, the customers probably will ignore it, and the review will be discounted. Furthermore, people agreement to become friends and reach each other's profiles, possibly will 
enhance the credibility of their contacts over time, and encourage more social trust. Therefore, the eWOM credibility in this research refers to the dependence degree of people on the contact list such as friends or peers etc, and not in the online message (review/comment) itself. Consequently, it can be hypothesized that:

H1: There is an impact of eWOM credibility on purchase intention.

\subsection{2 eWOM Quality}

The eWOM quality can be described as the convincing power of comments rooted in an informational message (Bhattacherjee, 2006). When customers are looking for information, the quality of information possibly will impact on customer's acceptance of it regarding eWOM communication channels (Cheung \& Thadani, 2009). According to Cheung (2008) Customer choice and buying decision can be built on certain criteria that meet their needs. For that reason, the extent to which provided information is helpful, clear, and easy to understand could be an essential request to determine student's perception of information quality as element for assessing their probable purchasing intention. Consequently, it can be hypothesized that:

H2: There is an impact of eWOM quality on purchase intention.

\subsection{3 eWOM Quantity}

When taking into consideration the huge quantity of information that individuals sharing online, most of them during shopping may possibly need a reference to strengthen their confidence to decrease the feeling of making mistakes or risks, because the online reviews'/comments quantity possibly be a sign of how much the product is valuable and popular. According to Lee et al. (2008) the amount of information customers received affect on customers decisions to purchase products and services. Furthermore, through product review websites, customers tend to believe negative comments more than the positive ones. A study by Sher and Lee (2009) on undergraduate student's attitudes after presenting them with product review websites to read showed that; students with less curiosity to read were simply influenced by the product reviews posted on the website. Besides the organizations official websites, the growing number of online blogs, web boards, chat rooms, product review websites and social networking sites; became the major sources of information that many customers read before making a decision to purchase products and services. Consequently, it can be hypothesized that:

H3: There is an impact of eWOM quantity on purchase intention.

\subsection{Corporate Image}

In general, customers intended to acquire products and services from a company with superior corporate image to reduce risks. According to (Keller, 1993) the term corporate image refers to a special associations held in customer memory for a certain company. Corporate image consider as one of the most important strategic resources that provide companies with the fertilize ground to build strong and long-term sustainable competitive advantage over competitors in the market (Boyd et al., 2010). There are many researches revealed that good image encourage customers commitment and facilitate brand extensions (Hem et al., 2003; Casalo et al., 2007). Corporate image facilitate customers' knowledge about the level of quality offered by a certain company, and decrease hesitation during the purchasing decision. In this research, the overall university image will be discussed through broad statement like how much potential students perceive the university as widely-known, the attractiveness of physical appearance, stability, likeability, and trustworthy. Consequently, it can be hypothesized that:

H4: The impact of eWOM credibility, eWOM quality, and eWOM quantity on purchase intention will be mediated by corporate image.

\subsection{Purchase Intention}

According to the literatures, purchase intention is one of the most prominent and popular variable resulting from eWOM communication (Sher \& Lee, 2009; Lee \& Lee, 2009). Customer's attitudes become favorable or unfavorable depending on the negative and positive amount of online customer reviews (Lee, Park, \& Han, 2008). Customers recommendations are positively associated with intentions to purchase, and in a straight line can affect customers' choices (Chang \& Chin, 2010). Customer reviews/comments and feedback are tremendously vital for online marketers. For both (online quality and online quantity) were found to have positive influence on customer's purchase intentions (Do-Hyung et al., 2007).

\section{Research Model}

Throughout a thorough analysis of eWOM literatures, the researcher proposed this model, as shown in figure (1), which includes three interrelated parts that are: Perceived eWOM which includes (eWOM credibility, eWOM quality, and eWOM quantity), corporate image, and finally the purchase intention. 


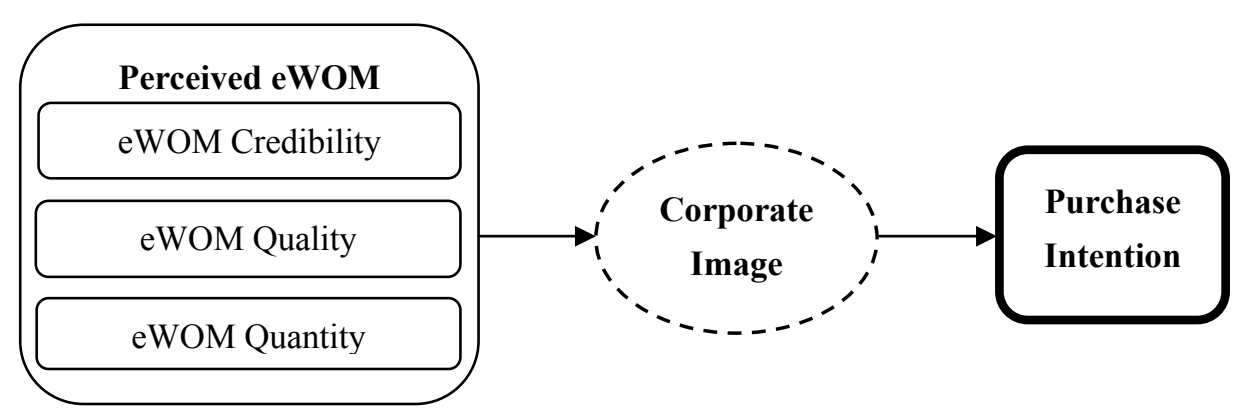

Figure 1. Proposed research model

\section{Research Methodology}

\subsection{Research Population and Sample}

The research population is defined as all secondary schools students in Jordan, for this research, Amman city is considered as a representative sample because it has diversity and population intensity at the same time. Students who are familiar with social networking sites, and have an active account of one or more of these social networking sites (Facebook, Twitter, Youtube, and Instagram), only get involved in this research, and that was an essential prerequisite. Convenience sampling technique has been used in data collection; the sample size was determined to be (1000) students. This was identified based on the number of items included in the questionnaire and the number of questionnaires needed for each item to have a stable statistical analysis (Hair et al., 2010). After using both electronic and traditional channels to distribute the 1000 questionnaires, unfortunately, 820 questionnaires were returned, the response rate $(82 \%)$ was relatively high, where the valid number of questionnaires used was (778) from the returned questionnaires.

\subsection{Questionnaire and Data Collection}

The research questionnaire was developed based on relevant literatures, and used to collect data from the research sample, the research variables measures and questionnaire statements adapted from previous researches. The questionnaire consisted of two parts as follows:

Part one: (asking respondents about general use of social networking sites; and respondent gender) this part consists of five main questions: (1) Which is the social networking site that you use frequently? (2) How often do you visit this social networking site on an average day? (3) What is the most activity do you usually do on this social networking site? (4) Roughly, how many university students do you know between your contacts on this social networking site? (5) Respondents gender.

Part two: collecting data for all research variables; the independent variables; perceived eWOM which includes (eWOM credibility, eWOM quality, and eWOM quantity), and the mediating variable (corporate image), and finally the dependent variable (purchase intention), using five-point Likert scale, ranging from (strongly disagree) to (strongly agree). Moreover, the research main statistical analytical tool is SPSS software.

\subsection{Research Validity and Reliability}

In this research, two types of validity have been used; the face validity and Content validity. Face validity was assessed through the pilot work of the research instrument with many experts in the field of this research, from well known Jordanian universities, who checked the suitability of the questionnaire to achieve the research objectives providing evidence of face validity. For content validity, the essential issue is the methodology used to build up the research questionnaire (Churchill and Brown, 2014). The research' instrument reliability has been assessed by testing the coefficient of Cronbach's alpha (Sekaran and Bougie, 2013). Table 1 show the reliability coefficients for all variables of this research, which ranged between $(0.694$ to 0.807$)$. In view of that, the research instrument and variables have a reasonable internal reliability coefficient. 
Table 1. Cronbach's alpha values

\begin{tabular}{ccc}
\hline Variables & Number of Items & Cronbach's Alpha \\
\hline eWOM credibility & 5 & 0.795 \\
eWOM quality & 5 & 0.807 \\
eWOM quantity & 3 & 0.730 \\
Corporate image & 8 & 0.795 \\
Purchase intention & 4 & 0.694 \\
\hline
\end{tabular}

\section{Data Analysis and Findings}

\subsection{Sample Characteristics}

Table 2 exhibits the research sample characteristics. A filtering question was used to reveal if each respondent has an active account on social networking sites to proceed in answering the questionnaire.

Table 2. Sample characteristics

\begin{tabular}{ccc}
\hline Variable & Frequency & Percent \\
\hline & The social networking site that used frequently & \\
Facebook & 338 & 43.4 \\
Twitter & 210 & 27.0 \\
YouTube & 136 & 17.5 \\
Instagram & 94 & 12.1 \\
\multicolumn{1}{c}{ Visiting this social networking site on an average day } & \\
1 & 224 & 28.8 \\
2 & 108 & 13.9 \\
3 & 314 & 40.4 \\
4 & 82 & 10.5 \\
5 & 50 & 6.4 \\
The most activity usually respondents do on this social networking site \\
Chatting & 360 & 46.3 \\
Posting comments & 86 & 11.1 \\
Making new friends & 126 & 16.2 \\
Searching products/services & 206 & 26.5 \\
Number of university students between contacts on this social networking site & 47.3 \\
Less than 5 & 368 & 29.6 \\
$6-10$ & 230 & 8.7 \\
11-15 & 68 & 14.4 \\
More than 15 & 112 & 53.7 \\
& Gender & 46.3 \\
Males & 418 & $\mathbf{1 0 0 . 0}$ \\
Females & 360 & \\
Total & $\mathbf{7 7 8}$ & \\
& &
\end{tabular}

Descriptive statistical analysis has been used to describe the sample characteristics. Table 2 shows the research sample characteristics using frequencies and percentages. Table 2 results show that $43.4 \%$ of secondary schools students are using the Facebook most frequently, and Twitter came the second with $27 \%$; this findings reflect the fact that the Facebook is still dominate the highest share between Jordanian users of social networking sites, which is consistent with the international statistics. Moreover, $40.4 \%$ of respondents on average are visiting their favorable social networking site three times a day, which means that they will be vulnerable to send or receive different types of information or content. In terms of the most activity usually respondents do on marked social networking site is chatting with average of $46.3 \%$, and then searching products/services with average of $26.5 \%$; this finding specify that respondents main concern in social networking sites is to connect and communicate with family, peers, friends, and colleagues, but they are also in ready to search of certain products and services from those of contact list. Furthermore, the majority of respondents mentioned that they have an university students between their contacts, $47.3 \%$ of respondents know less than five contacts as university students, and $29.6 \%$ of respondents have between 6-10 university students on the contact list; this finding points that the respondents will be open to receive reviews/comments from university students about their negative or positive experience in the university, which might influence respondents choices of universities in the future, and play a key role on 
shaping an good or bad image for discussed university on social networking site. Finally, the highest percentage of respondents are males representing $53.7 \%$ of total sample, while the females were $46.3 \%$; this finding is reasonable because Jordanian males are more interested in chatting with each other's, reading news, and to track the latest ads or offers related to finding jobs, clothing, sports, and so on.

\subsection{Hypothesis Testing}

With the purpose of testing the research hypotheses, the researcher depended on multiple regression analyses to examine the impact of independent variables perceived eWOM credibility, perceived eWOM quality, and perceived eWOM quantity on the dependent variable purchase intention.

H1: There is an impact of eWOM credibility on purchase intention.

As shown in table 3, the multiple regression model $(\mathrm{R}$ square $=0.287)$ is significant at 0.000 , and (beta $=0.536$, is significant at 0.000 ). Hence, the findings point out that there is a significant and positive impact of eWOM credibility on purchase intention. Thus, the overall findings offer support to accept H1. Furthermore, $(28.7 \%)$ of the variation in purchase intention can be explained by the eWOM credibility.

Table 3. Regression model summary for $\mathrm{H} 1$

\begin{tabular}{|c|c|c|c|c|c|c|}
\hline $\mathbf{R}$ & R Square & $\begin{array}{l}\text { Adjusted R } \\
\text { Square } \\
\end{array}$ & $\begin{array}{l}\text { Std. Error of the } \\
\text { Estimate }\end{array}$ & $\mathbf{F}$ & Sig. & H1 Result \\
\hline .536 & .287 & .286 & .59526 & 312.595 & $.000^{\mathrm{b}}$ & Accepted \\
\hline \multicolumn{7}{|c|}{ Coefficients } \\
\hline \multicolumn{2}{|c|}{$\begin{array}{l}\text { Unstandardized } \\
\text { Coefficients }\end{array}$} & $\begin{array}{c}\text { Standardized } \\
\text { Coefficients }\end{array}$ & & & & \\
\hline B & Std. Error & Beta & $\mathrm{T}$ & & Sig. & \\
\hline 2.338 & .104 & & 22.537 & & .000 & \\
\hline .458 & .026 & .536 & 17.680 & & .000 & \\
\hline
\end{tabular}

H2: There is an impact of eWOM quality on purchase intention.

As shown in table 4 , the multiple regression model $(\mathrm{R}$ square $=0.314)$ is significant at 0.000 , and (beta $=0.560$, is significant at 0.000 ). Hence, the findings point out that there is a significant and positive impact of eWOM quality on purchase intention. Thus, the overall findings offer support to accept H2. Furthermore, (31.4\%) of the variation in purchase intention can be explained by the eWOM quality.

Table 4. Regression model summary for $\mathrm{H} 2$

\begin{tabular}{ccccccc}
\hline $\mathbf{R}$ & R Square & $\begin{array}{c}\text { Adjusted R } \\
\text { Square }\end{array}$ & $\begin{array}{c}\text { Std. Error of the } \\
\text { Estimate }\end{array}$ & F & Sig. & H2 Result \\
\hline $.560^{\mathrm{a}}$ & .314 & .313 & .58411 & 354.562 & $.000^{\mathrm{b}}$ & Accepted \\
\hline \multicolumn{2}{c}{ Unstandardized } & Standardized & Coefficients & & & \\
\multicolumn{2}{c}{ Coefficients } & Coefficients & & & \\
B & Std. Error & Beta & $\mathrm{T}$ & & Sig. \\
2.245 & .102 & & 21.926 & .000 \\
.483 & .026 & .560 & 18.830 & .000 \\
\hline
\end{tabular}

H3: There is an impact of eWOM quantity on purchase intention.

As shown in table 5 , the multiple regression model $(\mathrm{R}$ square $=0.145)$ is significant at 0.000 , and (beta $=0.381$, is significant at 0.000 ). Hence, the findings point out that there is a significant and positive impact of eWOM quality on purchase intention. Thus, the overall findings offer support to accept H3. Furthermore, (14.5\%) of the variation in purchase intention can be explained by the eWOM quality. 
Table 5. Regression model summary for $\mathrm{H} 3$

\begin{tabular}{|c|c|c|c|c|c|c|}
\hline $\mathbf{R}$ & R Square & $\begin{array}{c}\text { Adjusted R } \\
\text { Square }\end{array}$ & $\begin{array}{l}\text { Std. Error of the } \\
\text { Estimate }\end{array}$ & $\mathbf{F}$ & Sig. & H2 Result \\
\hline .38 & .145 & .144 & .65174 & 132.118 & $.000^{\mathrm{b}}$ & Accepted \\
\hline \multicolumn{7}{|c|}{ Coefficients } \\
\hline \multicolumn{2}{|c|}{$\begin{array}{l}\text { Unstandardized } \\
\text { Coefficients }\end{array}$} & $\begin{array}{l}\text { Standardized } \\
\text { Coefficients }\end{array}$ & & & & \\
\hline B & Std. Error & Beta & $\mathrm{T}$ & \multicolumn{2}{|r|}{ Sig. } & \\
\hline 3.189 & .085 & & 37.341 & \multicolumn{2}{|r|}{.000} & \\
\hline .273 & .024 & .381 & 11.494 & \multicolumn{2}{|r|}{.000} & \\
\hline
\end{tabular}

H4: The impact of eWOM credibility, eWOM quality, and eWOM quantity on purchase intention will be mediated by corporate image.

As shown in table 6 , the multiple regression model $(\mathrm{R}$ square $=0.379)$ is significant at 0.000 . The findings point out that there is a significant and positive impact of eWOM credibility, eWOM quality, and eWOM quantity on purchase intention. Hence, the overall findings offer support to accept H4. Furthermore, (37.9\%) of the variation in purchase intention can be explained by the independent variables. According to weighted least square regression test (WLS) the findings point out that eWOM quality (beta is 0.308 , significant at 0.000 ), and eWOM credibility (beta is 0.280 , significant at 0.000 ) were the strongest predictors of variations respectively. Accordingly, and compared with the $\mathrm{R}$ square values in the previous tables; the overall impact of the independent variables on purchase intention is stronger through the corporate image.

Table 6. Regression model summary for $\mathrm{H} 4$

\begin{tabular}{|c|c|c|c|c|c|c|c|}
\hline $\mathbf{R}$ & R Square & \multicolumn{2}{|c|}{$\begin{array}{c}\text { Adjusted R } \\
\text { Square }\end{array}$} & $\begin{array}{l}\text { Std. Error of the } \\
\text { Estimate }\end{array}$ & $\mathbf{F}$ & Sig. & H4 Result \\
\hline $.616^{\mathrm{a}}$ & .379 & & & 1.07965 & 157.760 & $.000^{\mathrm{c}}$ & Accepted \\
\hline \multicolumn{8}{|c|}{ Coefficients } \\
\hline & & \multicolumn{2}{|c|}{$\begin{array}{l}\text { Unstandardized } \\
\text { Coefficients }\end{array}$} & \multicolumn{2}{|c|}{$\begin{array}{c}\text { Standardized } \\
\text { Coefficients }\end{array}$} & & \\
\hline \multirow{2}{*}{\multicolumn{2}{|c|}{ (Constant) }} & $\mathrm{B}$ & Std. Error & Beta & & $\mathrm{T}$ & Sig. \\
\hline & & 1.902 & .108 & & & 17.649 & .000 \\
\hline \multicolumn{2}{|c|}{ credibility } & .241 & .038 & .280 & & 6.312 & .000 \\
\hline \multirow{2}{*}{\multicolumn{2}{|c|}{$\begin{array}{l}\text { quality } \\
\text { quantity }\end{array}$}} & .268 & .042 & .308 & & 6.424 & .000 \\
\hline & & .075 & .024 & .105 & & 3.065 & .002 \\
\hline
\end{tabular}

\section{Results Discussion and Conclusion}

Prior researches have studied the impact of traditional word of mouth on customer behavior; by means of the extensive development in electronic word of mouth, marketer's needs to better recognize and analyze how eWOM might influence customer's intention to purchase certain product. The findings of the multiple regression analyses point out that there is a significant and positive impact of the independent variables (eWOM credibility, eWOM quality, and eWOM quantity) on the dependent variable purchase intention. As well as, the corporate image was found to mediate the relationship between the independent variables and the dependent variable. The findings provide support for the eWOM literatures, which advocate that a trust in people on contact list, the easiness of understanding the message (reviews/comments), and the volume of the message through social networking sites would be able to attract and influence the purchasing decision of prospects customers. Moreover, based on beta values and significance; the findings indicated that eWOM quality is the most influential dimension (predictor) on purchase intention; this results is consistent with previous literatures (Do-Hyung et al. 2007; Cheung \& Thadani, 2009), and respectively; eWOM credibility (Mangold \& Faulds, 2009), eWOM quantity (Do-Hyung et al., 2007; Lee et al., 2008). Furthermore, the multiple regression analyses findings indicate that the corporate image positively mediate and strengthen the relationships between the perceived eWOM variables and the purchase intention; according to the researcher best knowledge; this result is new to the eWOM literatures, and might be supported by other researchers in the future. Accordingly, online reviews/comments are useful for universities prospects students, because it can make them sense and believe that they are taking a reasonable purchasing decision. Furthermore, understandable, helpful, and convincing reviews/comments about the university; possibly will have a powerful impact on schools students purchasing 
intention. Hence, Managing and supervising online reviews/comments provided by university students can be applied as a communication tool. For instance, the admin of social networking sites at the university could provide easy and attractive formats that allow university students to share and post their best experience with prospect students.

\section{Recommendations and Future Research}

Based on the research empirical findings; it seems that using social networking sites for different purposes are very high between Jordanians customers, especially those of our research (schools students and university students), for that reason, marketers need to discover the most appropriate platforms, where their potential buyers are interacting. As mentioned earlier, Jordanian universities have intangible product, so they need to gather more and more information about their prospects, to build and create distinctive competitive advantage that affects target students purchase intention in the future. Through monitoring online reviews/comments provided by students in the university; all universities in Jordan can forecast the future demand. As well as, universities might be capable to encourage their current students to share and post large and high quality of reviews/comments; by using the most common social networking sites between universities students and schools students. Besides that, universities may reward best reviews/comments; or arrange contest for the most attractive content.

Finally, future research in this field may take another sample, or to extend the research model based on latest literatures, in order to enrich this growing area of research. Moreover, other researchers might take the universities attitudes toward using social networking sites in their marketing strategy.

\section{Acknowledgement}

The author is grateful to the applied science private university, Amman, Jordan, for the full financial support granted to this research project (DRGS-2014-2015-40).

\section{References}

Bhattacherjee, A. A. S. (2006). Influence process for information technology acceptance: an elaboration likelihood model. MIS Quarterly, 30(4), 805-825.

Boyd, B. K., Bergh, D. D., \& Ketchen Jr., D. J. (2010). Reconsidering the reputation-performance relationship: A resource-based view. Journal of Management, 36(3), 588-609. http://dx.doi.org/10.1177/0149206308328507

Breazeale, M. (2009). Word of mouse. International Journal of Market Research, 51(3), 297-318.

Casalo, L. V., Flavian, C., \& Guinaliu, M. (2007). The influence of satisfaction, perceived reputation and trust on a customer's commitment to a website. Journal of Marketing Communications, 13(1), 1-17.

Chang, C. C., \& Chin, Y. C. (2010). The impact of recommendation sources on online purchase intentions: the moderating effects of gender and perceived risk. World Academy of Science, Engineering and Technology, 66(June), 111-114.

Cheung, C. M. K., Lee, M. K. O., \& Thadani, D. R. (2009). The Impact of Positive Electronic Word-of-Mouth on Customer Online Purchasing Decision. In M. D. Lytras, E. Damiani, J. M. Carroll, R. D. Tennyson, D. Avison, A. Naeve, A. Dale, P. Lefrere, F. Tan, J. Sipior, \& G. Vossen (Eds.), Lecture Notes in Computer Science (Lecture Notes in Artificial Intelligence) (Vol. 5736, pp. 501-510). Springer-Verlag Berlin Heidelberg.

Cheung. E. A. (2008). The impact of electronic word-of-mouth: The adoption of online opinions in online customer communities. Internet Research, 18(3), 229-247. http://dx.doi.org/10.1108/10662240810883290

Churchill, GA \& Brown TJ. (2014). Basic Marketing Research (8th Ed.). Cengage Learning.

Do-Hyung, P., Jumin, L., \& Ingoo, H. (2007). The Effect of On-Line Customer Reviews on Customer Purchasing Intention: The Moderating Role of Involvement. International Journal of Electronic Commerce, 11(4), 125-148.

Duan, W., Gu, B., \& Whinston, A. (2008). Do online reviews matter? - An empirical investigation of panel data. Decision Support Systems, 45(4), 1007.

EMarketer. (August, 2014). Can Customers-Read-More-Local-Online-Reviews Thanks Rumors of Fakes? Retrieved from http://www.emarketer.com/Article.aspx?R=1011078 
Fogg, B. J., Kameda, T., Boyd, J., Marshall, J., Sethi, R., Sockol, M., \& Trowbridge, T. (2002). Stanford Makovsky Web Credibility Study 2002: Investigating What Makes Web Sites Credible Today. A Research Report by the Stanford Persuasive Technology Lab \& Makovsky \& Company, Stanford University. Retrieved from www.webcredibility.org

Frambach, R. T., Roest, H. C. A., \& Krishnan, T. V. (2007). The impact of customer Internet experience on channel preference and usage intentions across the different stages of the buying process. Journal of Interactive Marketing, 21(2), 26-41.

Gil-Or, O. (July 2010). Building Customer Demand by using Viral Marketing Tactics within an Online Social Network. Advances in Management, 3(7), 7-14.

Goldsmith, R. E., \& Horowitz, D. (2006). Measuring Motivations for Online Opinion Seeking. Journal of Interactive Advertising, 6(2), 1-16. http://dx.doi.org/10.1080/15252019.2006.10722114

Hair, J.F., Jr., Black, W.C., Babin, B.J. \& Anderson, R.E. (2010). Multivariate Data Analysis. 7th ed., Prentice Hall, Upper Saddle River, N.J.

Hem, L. E., de Chernatony, L., \& Iversen, N. M. (2003). Factors influencing successful brand extensions. Journal of Marketing Management, 19(7/8), 781-806. http://dx.doi.org/10.1080/0267257X.2003.9728237

Hennig-Thurau, F., Gwinner, K. P., Walsh, G., \& Gremler, D. D. (2004). Electronic Word-of-Mouth via Customer-Opinion Platforms: What Motivates Customers to Articulate Themselves On the Internet? Journal of Interactive Marketing, 18(1), 38-52.

Hilligoss, B., \& Rieh, S. Y. (2008). Developing a unifying framework of credibility assessment: Construct, heuristics, and interaction in context. Information Processing and Management, 44(4), 1467-1484. http://dx.doi.org/10.1016/j.ipm.2007.10.001

Jalilvand, M. R., Esfahani, S. S., \& Samiei, N. (2011). Electronic word-ofmouth: Challenges and opportunities. Procedia Computer Science, 3, 42-46.

Keller, K. L. (1993). Conceptualizing, measuring, and managing costumer-based brand equity. Journal of Marketing, 57, 1-22.

Kozinets, R., de Valck, K., Wojnicki, A., \& Wilner, S. (2010). Networked Narratives: Understanding Word-of-Mouth Marketing in Online Communities. Journal of Marketing, 74(2), 71-89.

Lee, J., \& Lee, J. N. (2009). Understanding the product information inference process in electronic word-of-mouth: An objectivity-subjectivity dichotomy perspective. Information \& Management, 46(5), 302. http://dx.doi.org/10.1016/j.im.2009.05.004

Lee, J., Park, D. H., \& Han, I. (2008). The effect of negative online customer reviews on product attitude: An information processing view. Electronic Commerce Research and Applications, 7(3), 341-352.

Lin, C., Wu, Y., \& Chen, J. (2013). Electronic Word-Of-Mouth: The Moderating Roles Of Product Involvement And Brand Image. Proceedings of 2013 international conference on technology innovation and industrial management, Phuket, Thailand.

Mangold, W. G., \& Faulds, D. J. (2009). Social media: the new hybrid element of the promotion mix. Business Horizons, 52(4), 357-365. http://dx.doi.org/10.1016/j.bushor.2009.03.002

Park, D. H., \& Lee, J. (2008). eWOM overload and its effect on customer behavioral intention depending on customer involvement. Electronic Commerce Research and Applications, 7(4), 386.

San José-Cabezudo, R., \& Camarero-Izquierdo, C. (2012). Determinants of Opening Forwarding E-Mail Messages. Journal of Advertising; Summer2012, 41(2), 97-112.

Sekaran, U., Bougie, R. (2013). Research Methods for Business (6th ed.). John Wiley \& Sons, Inc.

Senecal, S., \& Nantel, J. (2004). The influence of online product recommendations on customers' online choices. Journal of Retailing, 80(2), 159-169.

Sher, P. J., \& Lee, S. H. (2009). Customer skepticism and online reviews: An elaboration likelihood model perspective. Social Behavior and Personality, 37(1), 137-144.

Shu-Chuan, C., \& Yoojung, K. (2011). Determinants of Customer Engagement in Electronic Word-of-Mouth (eWOM) in Social Networking Sites. International Journal of Advertising, 30(1), 47-75. 
Strutton, D., Taylor, D. G., \& Thompson, K. (2011). Investigating generational differences in e-WOM behaviours. International Journal of Advertising, 30(4), 559-586.

Sweeney, J. C., Soutar, G. N., \& Mazzarol, T. (2008). Factors influencing word of mouth effectiveness: receiver $\begin{array}{lllll}\text { perspectives. } \quad \text { European Journal of } & \text { 344-364. }\end{array}$ http://dx.doi.org/10.1108/03090560810852977

Yeh, Y-H., \& Choi, S. M. (2011). MINI-lovers, maxi-mouths: An investigation of antecedents to eWOM intention among brand community members. Journal of Marketing Communications, 17(3), 145-162. http://dx.doi.org/10.1080/13527260903351119.

Zhang, W., \& Watts, S. A. (2008). Capitalizing on Content: Information Adoption in Two Online communities. Journal of the Association for Information Systems, 9(2), 73-94.

\section{Appendix A}

\section{Research Questionnaire}

Part (1) Sample characteristics:

This section is concerned with asking respondents about general use of social networking sites and gender; please mark (X) for the most appropriate answer for you in the following questions?

1. Which is the social networking site that you use frequently?

$\begin{array}{ll}\text { Facebook } & (\quad) \\ \text { Twitter } & (\text { ) } \\ \text { YouTube } & (\quad) \\ \text { Instagram } & (\quad)\end{array}$

2. How often do you visit this social networking site on an average day?

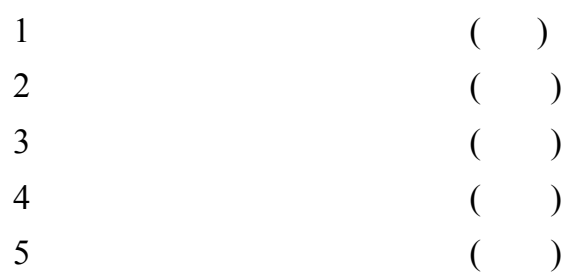

3. What is the most activity do you usually do on this social networking site?

Chatting

Posting comments

Making new friends

Searching products/services

4. Roughly, how many university students do you know between your contacts on this social networking site?

Less than 5

$6-10$

$11-15$

More than 15

5. Gender:

Male

Female 
Part (2) This section is concerned with asking questions about the research variables; the independent variable perceived eWOM which includes (eWOM credibility, eWOM quality, and eWOM quantity), and the mediating variable (corporate image), and finally the dependent variable (purchase intention), using five-point Likert scale, ranging from (strongly disagree) to (strongly agree). For each statement please mark (X) in the box which best describes your opinion to what extent you agree or disagree with each described statement.

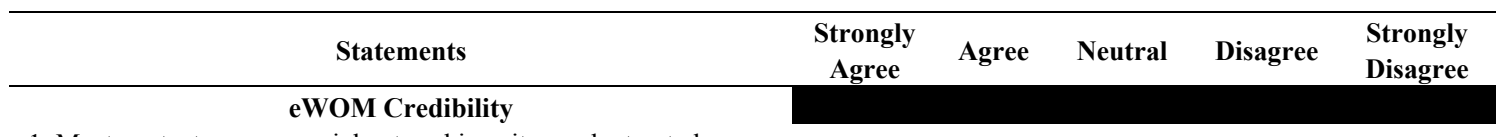

1. Most contacts on my social networking site can be trusted.

2. I feel confident about having discussions with the contacts on my social networking site.

3. The contacts on my social networking site will do everything within their capacity to help others.

4. My contacts on my social networking site always offer honest opinions.

5. I can believe in the contacts on my social networking site. eWOM Quality

6. The online reviews/comments provided by university students on my social networking site are clear.

7. The online reviews/comments provided by university students on my social networking site are understandable.

8 . The online reviews/comments provided by university students on my social networking site are helpful.

9. The online reviews/comments provided by university students on my social networking site have sufficient reasons supporting the opinions.

10. Overall, the quality of each online reviews/comments provided by university students on my social networking site is high.

\section{eWOM Quantity}

11. The number of online reviews/comments provided by university students is large, inferring that the university is popular. 12. The quantity of online reviews/comments provided by university students is great, inferring that the university is trendy. 13. Highly ranking and recommendations, inferring that the university provides high quality services.

\section{Corporate Image}

14. The university discussed in the online reviews/comments is widely-known.

15. The university discussed in the online reviews/comments has a good physical appearance.

16. The university discussed in the online reviews/comments always involve in social works.

17. The university discussed in the online reviews/comments is well liked from students.

18. The university discussed in the online reviews/comments has a distinguish image from others.

19. The university discussed in the online reviews/comments has a deep experience in the market.

20. The university discussed in the online reviews/comments is stable.

21. The university discussed in the online reviews/comments is trustworthy.

\section{Purchase Intention}

22. After reading online reviews/comments, provided by university students it makes me desire to join this university. 23. I intend to seek more reviews/comments provided by university students on my social networking site.

24 . I intend to visit the university discussed in the online reviews/comments.

25. In the future, I will consider the university discussed in the online reviews/comments as my first choice. 


\section{Copyrights}

Copyright for this article is retained by the author(s), with first publication rights granted to the journal.

This is an open-access article distributed under the terms and conditions of the Creative Commons Attribution license (http://creativecommons.org/licenses/by/3.0/). 